\title{
SKIRTINGOSE LIETUVOS VIETOVÉSE SURINKTŲ ŽIEDADULKIŲ EKSTRAKTO ANTIMIKROBINIS VEIKIMAS
}

\author{
Žaneta Maželien $\dot{e}^{1,2}$, Gintarẻ Lingyte் ${ }^{1}$, Evelina Dailidaité ${ }^{1}$, Ingrida Viliušiené ${ }^{1}$ \\ ${ }^{1}$ Kauno kolegijos Medicinos fakultetas, Medicinos technologiju ir dietetikos katedra, \\ ${ }^{2}$ Lietuvos sveikatos moksly universitetas, Virusologijos ir mikrobiologijos institutas
}

\author{
Raktažodžiai: bičių žiedadulkès, antimikrobinis veiki- \\ mas, mikroorganizmai.
}

\section{Santrauka}

Itvadas. Pasaulio sveikatos organizacijos (PSO) duomenimis, bakterijų atsparumas antibiotikams kelia didelę grèsmę visame pasaulyje ir sunkina infekcinių ligų gydymą [1]. Manoma, kad apie 70 proc. bakterijų, kurios sukelia infekcinius susirgimus ligoninèse, yra atsparios bent vienam iš gydymui naudojamų antibiotikų. Ši situacija skatina ieškoti kitų sprendimų, vienas iš jų - bičiu produktus naudoti kaip natūralius antibiotikus dèl jų antimikrobinio veikimo.

Tyrimo tikslas - nustatyti skirtingose Lietuvos vietovèse surinktų žiedadulkių ekstraktų antimikrobinį veikimą. Tyrimo metodika. Atliktas įvairiuose Lietuvos ūkiuose surinktų žiedadulkių skirtingos koncentracijos ekstraktų mikrobiologinis tyrimas. Nustatytas 50 žiedadulkių ekstraktų mėginių antimikrobinis poveikis dešimties etaloninių bakterijų kultūrų ir grybelio Candida albicans atžvilgiu. Tyrimo duomenų analizé atlikta naudojant aprašomają statistiką, skaičiuojant dažnius bei grupių palyginimą pagal Kruskal Wallis, tyrimo duomenys apdoroti Microsoft Excel 2019 programa.

Tyrimo rezultatai. Nustatyta, kad stipriausią antimikrobinį poveikị turėjo D žiedadulkių, surinktų Kaišiadoriu rajone, ekstraktas. D ekstrakto antimikrobinis poveikis Staphylococcus epidermidis, Pseudomonas aeruginosa, Bacillus cereus, Listeria monocytogenes atžvilgiu nustatytas esant 0,025 ml ekstrakto 1 agaro ml. Staphylococcus aureus, Enterococcus faecalis, Klebsiella pneumoniae, Proteus vulgaris ir grybeli Candida albicans, išskyrus Escherichia coli, ekstraktas veikè esant jo 0,0375-0,05 $\mathrm{ml}$ agaro $1 \mathrm{ml}$. Žiedadulkių ekstraktas gramteigiamąsias bakterijas veikia stipriau, lyginant su gramneigiamosiomis. Šis skirtumas siejamas su gramteigiamu ir gramneigiamų bakterijų ląstelès sienelès struktūros skirtumais.
Išvados. Stipriausią antimikrobinị veikimą turi žiedadulkès, surinktos Kaišiadorių rajone. Nustatyta, kad žiedadulkių ekstraktai stipriau veikia gramteigiamąsias bakterijas, lyginant su gramneigiamosiomis.

\section{Ivadas}

Tikra gamtos dovana - taip senojoje lietuvių literatūroje vadinamos žiedadulkès. Apie jų stebuklingą poveiki parašyta ne viena knyga, o medicinoje jos tapo nepakeičiama imuniteto stiprinimo priemone. Žiedadulkès - vienintelis natūralus biokompleksas taip ilgai ir sèkmingai taikomas žmogaus gyvenime. Bičių surinktas žiedadulkes rekomenduojama vartoti ne tik kaip maisto produktą, bet ir kaip profilaktikos priemonę, sergant ateroskleroze, virškinamojo trakto ligomis, lètiniu hepatitu, tulžies pūslès uždegimu. Žiedadulkès padeda esant prostatos susirgimams, klimakterinèms neurozèms, nervinei depresijai bei lètiniui alkoholizmui. Jų vartojimas grąžina organizmui jègas po infekcinių ligų ir gerina nuotaiką.

Žiedadulkès maistui ir vaistams pradètos vartoti palyginti neseniai. Su šiuo produktu žmonės susipažino tik XX a. septintojo dešimtmečio pabaigoje, nors Rytų Europos šalyse ir Amerikoje žiedadulkès buvo renkamos nuo Antrojo pasaulinio karo pabaigos. Šiuo metu žiedadulkès dèl jose esančių medžiagų yra labai paklausus produktas, užimantis svarbią vietą tarp kitų bičių produktų. Jos vartojamos maistui ir vaistams, veterinarijoje bei kosmetikoje.

Bičių žiedadulkès vertingos medicininiu požiūriu dèl savo cheminès sudèties - jose gausu natūralių cukrų, vitaminų, mineralų, aminorūgščių, organinių rūgščių, baltymų, karotinoidų, flavonoidų, sterolių [2]. Atskiros žiedadulkių cheminių junginių grupès, kaip organinès rūgštys, karotinoidai, flavonoidai ir flavanoliai, suteikia antimikrobinių, antioksidantinių bei farmokologinių savybių. Nustatyta, kad apie 70 proc. bakterijų, kurios sukelia infekcinius susirgimus ligoninèse, yra atsparios bent vienam iš gydymui naudojamų antibiotikų [3]. Ši situacija skatina ieškoti kitų sprendimų, 
vienas iš jų - bičių produktus naudoti kaip natūralius antibiotikus dẻl jų antimikrobinio veikimo infekcijų sukèlëjus.

Atliktų tyrimų rezultatai rodo, kad bičių žiedadulkių ekstraktai antimikrobiškai veikia gramteigiamas (Staphylococcus aureus ir Staphylococcus epidermidis), gramneigiamas (Escherichia coli, Enterobacter cloacae, Klebsiella pneumoniae, Pseudomonas aeruginosa) bei žmonèms patogeniškus Candida genties grybus $[4,5]$. Mokslinès literatūros analizè atskleide [4-6], kad analizuojamas žiedadulkių ekstrakto antimikrobinis veikimas įvairiose pasaulio šalyse. Mažai atlikta tyrimų, kuriuose būtų nagrinėjamas Lietuvoje surinktų žiedadulkiu ekstrakto antimikrobinis veikimas. Šiame tyrime siekiama ịvertinti įvairiose Lietuvos vietovèse surinktų žiedadulkių, ekstraktų antimikrobinị poveikị mikroorganizmams.

Tyrimo tikslas - nustatyti ịvairiose Lietuvos vietovèse surinktų žiedadulkių ekstraktų antimikrobinį veikimą.

\section{Tyrimo metodika}

Tyrime naudojamos žiedadulkès, surinktos 2020 metu pavasari ir vasarą penkiuose Lietuvos vietovių ūkiuose: Anykščių (A ekstraktas), Kupiškio (B ekstrak- tas), Zarasų (C), Kaišiadorių (D) ir Vilniaus (E) rajonuose.

Bičių žiedadulkių ekstrakto paruošimas. Žiedadulkès po $5 \mathrm{~g}$ dedamos ị sterilius sandarius indus, užpilamos $20 \mathrm{ml}$ 96 proc. etanoliu ir 14 parų laikomos tamsoje kambario temperatūroje. Po 14 parų ekstrakcijos filtruojamos ir supilamos i sterilius ir sandarius mėgintuvèlius [7]. Žiedadulkių ekstraktų antimikrobinis veikimas nustatytas in vitro standartinių (etaloninių) gramteigiamujų bakterijų Staphylococcus aureus ATCC 25923, Staphylococcus epidermidis ATCC 12228, Enterococcus faecalis ATCC 29212 ir Listeria monocytogenes ATCC 19115, gramneigiamujų bakterijų Escherichia coli ATCC 25922, Klebsiella pneumoniae ATCC 13883, Pseudomonas aeruginosa ATCC 27853 ir Proteus vulgaris ATCC 8247, sporinès bakterijos Bacillus cereus ATCC 11778, ir grybelio Candida albicans ATC 10231 kultūrų atžvilgiu remiantis EARSS (European Antimicrobial Resistance Surveillance System) ir EUCAST (The Eurovopean Committee on Antimicrobial Susceptibility Testing) reglamentuotomis metodikomis ir vertinimo kriterijais. Etaloninès bakterijų ir grybelio Candida albicans kultūros buvo auginamos 20-24 val. $35-37{ }^{\circ} \mathrm{C}$ temperatūroje ant Mueller-Hinton agaro $(\mathrm{Mu}-$

1 lentelè. A, B, C, D ir E ekstraktų antimikrobinis veikimas ị gramteigiamąsias bakterijas.

,"+ - tiriamas ekstrakto kiekis slopina mikroorganizmo angima terpéje;

,-“ - tiriamas ekstrakto kiekis neslopina mikroorganizmo augimo terpejje.

\begin{tabular}{|c|c|c|c|c|c|c|c|c|c|c|c|c|c|c|c|c|c|c|c|c|}
\hline \multirow{3}{*}{ 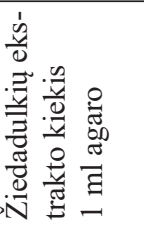 } & \multicolumn{20}{|c|}{ Mikroorganizmai ir tiriamieji ekstraktai } \\
\hline & \multicolumn{5}{|c|}{$\begin{array}{c}\text { Staphylococcus } \\
\text { aureus }\end{array}$} & \multicolumn{5}{|c|}{$\begin{array}{l}\text { Staphylococcus } \\
\text { epidermidis }\end{array}$} & \multicolumn{5}{|c|}{$\begin{array}{l}\text { Enterococcus } \\
\text { faecalis }\end{array}$} & \multicolumn{5}{|c|}{$\begin{array}{c}\text { Listeria } \\
\text { monocytogenes }\end{array}$} \\
\hline & A & $\mathrm{B}$ & $\mathrm{C}$ & $\mathrm{D}$ & $\mathrm{E}$ & A & $\mathrm{B}$ & $\mathrm{C}$ & $\mathrm{D}$ & $\mathrm{E}$ & A & $\mathrm{B}$ & $\mathrm{C}$ & $\mathrm{D}$ & $\mathrm{E}$ & A & $\mathrm{B}$ & $\mathrm{C}$ & $\mathrm{D}$ & $\mathrm{E}$ \\
\hline $0,005 \mathrm{ml}$ & - & - & - & - & - & - & - & - & - & - & - & - & - & - & - & - & - & - & - & - \\
\hline $0,0125 \mathrm{ml}$ & - & - & - & - & - & - & + & - & - & - & - & - & - & - & - & - & - & - & - & - \\
\hline $0,025 \mathrm{ml}$ & - & - & - & - & - & - & + & - & + & - & - & - & - & - & - & + & - & + & + & - \\
\hline $0,0375 \mathrm{ml}$ & - & - & - & - & - & + & + & + & + & - & + & + & - & + & - & + & - & + & + & - \\
\hline $0,05 \mathrm{ml}$ & - & + & - & + & - & + & + & + & + & + & + & + & - & + & - & + & + & + & + & + \\
\hline
\end{tabular}

2 lentelè. A, B, C, D ir E ekstraktų antimikrobinis veikimas ị gramneigiamąsias bakterijas.

„,+ - tiriamas ekstrakto kiekis slopina mikroorganizmo augima terpéje;

„,-“ - tiriamas ekstrakto kiekis neslopina mikroorganizmo augimo terpéje.

\begin{tabular}{|c|c|c|c|c|c|c|c|c|c|c|c|c|c|c|c|c|c|c|c|c|}
\hline \multirow{3}{*}{ 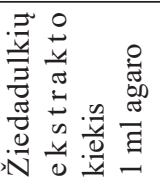 } & \multicolumn{20}{|c|}{ Mikroorganizmai ir tiriamieji ekstraktai } \\
\hline & \multicolumn{5}{|c|}{ Escherichiae coli } & \multicolumn{5}{|c|}{ Klebsiella pneumoniae } & \multicolumn{5}{|c|}{ Pseudomonas aeruginosa } & \multicolumn{5}{|c|}{ Proteus vulgaris } \\
\hline & A & B & $\mathrm{C}$ & $\mathrm{D}$ & $\mathrm{E}$ & A & B & $\mathrm{C}$ & $\mathrm{D}$ & $\mathrm{E}$ & A & $\mathrm{B}$ & $\mathrm{C}$ & $\mathrm{D}$ & $\mathrm{E}$ & A & B & $\mathrm{C}$ & $\mathrm{D}$ & $\mathrm{E}$ \\
\hline $0,005 \mathrm{ml}$ & - & - & - & - & - & - & - & - & - & - & - & - & - & - & - & - & - & - & - & - \\
\hline $0,0125 \mathrm{ml}$ & - & - & - & - & - & - & - & - & - & - & - & - & - & - & - & - & - & - & - & - \\
\hline $0,025 \mathrm{ml}$ & - & - & - & - & - & - & - & - & - & - & + & - & + & + & - & - & - & - & - & - \\
\hline $0,0375 \mathrm{ml}$ & - & - & - & - & - & - & - & - & - & - & + & - & + & + & + & - & - & - & + & - \\
\hline $0,05 \mathrm{ml}$ & - & - & - & - & - & - & - & - & + & - & + & - & + & + & + & + & - & - & + & - \\
\hline
\end{tabular}


eller-Hinton II Agar, BBL, Cockeysville, JAV), mikroorganizmų suspensijos paruoštos fiziologiniame natrio chlorido (0,9 proc.) tirpale ir standartizuotos McFarland standartiniu indikatoriumi (Standart indikator McFarland).

Žiedadulkių ekstraktų antimikrobinis veikimas nustatytas difuzijos ị standujj mitybinị agarą būdu. Kiekvieno ekstrakto antimikrobinis aktyvumas tirtas 5 Petri lèkštelèse: i 1 mikropipete pilama $0,1 \mathrm{ml}$ tiriamo ekstrakto, i $2-0,25$ $\mathrm{ml}$, i $3-0,5 \mathrm{ml}$, i $4-0,75 \mathrm{ml}$ ir ị 5- $1 \mathrm{ml}$ tiriamojo ekstrakto. Po to ị kiekvieną Petri lèkštelę su ekstraktu pilama $20 \mathrm{ml}$ ištirpinto ir atvėsinto iki $45^{\circ} \mathrm{C}$ temperatūros Mueller-Hinton agaro (Mueller-Hinton Agar, Becton, Dickinson and Company). Sustingus agarui su ekstraktu, ị kiekvieną segmentą 1 $\mu \mathrm{l}$ bakteriologine kilpele sejjama etaloninè mikroorganizmu kultūra. Pasèliai kultivuoti termostate $20-24$ val. $30-35{ }^{\circ} \mathrm{C}$ temperatūroje. Po inkubacijos termostate vertintas tirtuju méginių antimikrobinis veikimas - auga ar neauga tiriamųjų mikroorganizmų kultūros. Tyrimo patikimumui užtikrinti atlikta kontrolè - Mueller-Hinton agare pasetos visos tiriamos mikroorganizmu kultūros ir inkubuojamos termostate 20-24 val. $30-35{ }^{\circ} \mathrm{C}$ temperatūroje. Tyrimo duomenų analizè atlikta naudojant aprašomąją statistiką, skaičiuojant dažnius bei grupių palyginimą pagal Kruskal Wallis, tyrimo duomenys apdoroti Microsoft Excel 2019 programa.

\section{Tyrimo rezultatai ir jų aptarimas}

Tiriant A, B, C, D ir E ekstraktu antimikrobini poveiki nustatyta, kad jis yra skirtingas gramteigiamujų ir gramneigiamujų bei sporinių bakterijų ir grybelio Candida albicans atžvilgiu. Nustatyta, kad ekstraktų kiekis 0,005 ir 0,0125 $\mathrm{ml} 1 \mathrm{ml}$ agaro neturi antimikrobinio poveikio tirtoms gramteigiamujjų bakterijų kultūroms (1 lentelè). Staphylococcus aureus tirtose koncentracijose neveikia A, C ir E žiedadulkių ekstraktai, o Enterococcus faecalis - C ir E ekstraktai. Staphylococcus epidermidis, Enterococcus faecalis ir Listeria monocytogenes augimą slopino ekstraktų kiekis $0,05 \mathrm{ml} 1 \mathrm{ml}$ agaro.

Gramneigiamosios bakterijos, lyginant su gramteigiamosiomis, mažiau jautrios tirtiems žiedadulkių ekstraktams (2 lentelè). Klebsiella pneumoniae ir Escherichiae coli buvo nejautrios tirtiems ekstraktų kiekiams $1 \mathrm{ml}$ agaro. Pseudomonas aeruginosa antimikrobiškai veike A, C, D ir E ekstraktai, esant jų kiekiui $1 \mathrm{ml}$ agaro $0,025 \mathrm{ml}$ ir didesniame. Proteus vulgaris augimą slopino A ir D ekstraktai, esant jų kiekiui $1 \mathrm{ml}$ agaro 0,0375 $\mathrm{ml}$ ir didesniame.
Candida albicans augimo neslopino visi ekstratai, išskyrus D ekstraktą esant jo kiekiui $1 \mathrm{ml}$ agaro $0,05 \mathrm{ml}$ (3 lentelè). Sporinè bakterija Bacillus cereus buvo jautri tirtiems ekstraktų kiekiams $1 \mathrm{ml}$ agaro.

Atlikus statistinę duomenų analizę (grupių palyginimą pagal Kruskal Wallis), nustatytas statistiškai reikšmingas skirtumas $(\mathrm{p}<0,005)$ tarp tam tikrų mikroorganizmų jautrumo žiedadulkių ekstraktui ir žiedadulkių ekstrakto kiekio $1 \mathrm{ml}$ agaro (4 lentelè).

Statistiškai reikšmingas skirtumas $(\mathrm{p}<0,005)$ aptiktas tiriant Staphylococcus epidermidis, Enterococcus faecalis, Bacillus cereus, Listeria monocytogenes ir Pseudomonas aeruginosa. Tai įrodo, jog didejjant žiedadulkių ekstrakto kiekiui, stebimas jo antimikrobinis poveikis tirtoms mikroorganizmų kultūroms.

3 lentelè. A, B, C, D ir E ekstraktų antimikrobinis veikimas ị sporinę bakteriją Bacillus cereus ir grybeli Candida albicans.

,, " - tiriamas ekstrakto kiekis slopina mikroorganizmo augima terpeje;

,_-“ - tiriamas ekstrakto kiekis neslopina mikroorganizmo augimo terpeje.

\begin{tabular}{|l|c|c|c|c|c|c|c|c|c|c|}
\hline \multirow{2}{*}{$\begin{array}{l}\text { Žiedadulkiu } \\
\text { ekstrakto } \\
\text { kiekis }\end{array}$} & \multicolumn{9}{|c|}{ Mikroorganizmai ir tiriamieji ekstraktai } \\
\cline { 2 - 12 } & \multicolumn{5}{|c|}{ Bacillus cereus } \\
\cline { 2 - 11 } & A & B & C & D & E & A & B & C & D & E \\
\hline $0,005 \mathrm{ml}$ & - & + & - & - & - & - & - & - & - & - \\
\hline $0,0125 \mathrm{ml}$ & - & + & - & - & - & - & - & - & - & - \\
\hline $0,025 \mathrm{ml}$ & + & + & + & + & + & - & - & - & - & - \\
\hline $0,0375 \mathrm{ml}$ & + & + & + & + & + & - & - & - & - & - \\
\hline $0,05 \mathrm{ml}$ & + & + & + & + & + & - & - & - & + & - \\
\hline
\end{tabular}

4 lentelè. Statistiškai reikšmingo skirtumo skaičiavimas tarp žiedadulkių ekstrakto koncentracijos ir mikroorganizmų išaugimo.

\begin{tabular}{|c|c|c|c|c|c|c|c|c|c|c|c|c|}
\hline & & & & & & ikro & rga & nizm & & & & \\
\hline 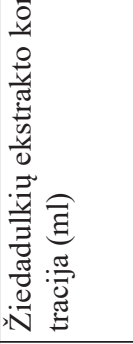 & 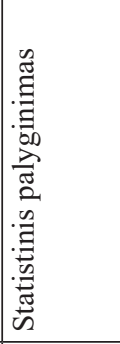 & 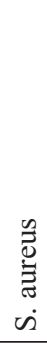 & 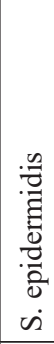 & 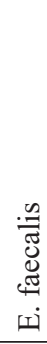 & $\begin{array}{l}\overline{0} \\
0 \\
\end{array}$ & 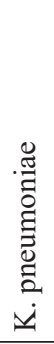 & 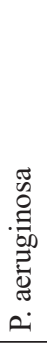 & $\begin{array}{l}\mathscr{a} \\
\bar{\Xi} \\
\dot{\Xi} \\
\dot{0}\end{array}$ & 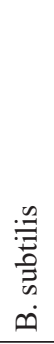 & 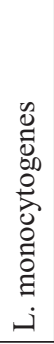 & $\begin{array}{l}\tilde{\tilde{U}} \\
\stackrel{0}{0} \\
\overrightarrow{0} \\
\dot{0}\end{array}$ & 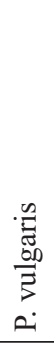 \\
\hline $0,005 \mathrm{ml}$ & \multirow{5}{*}{$\begin{array}{l}\mathrm{P}(\text { sig) } \\
\text { reikšme }\end{array}$} & \multirow{5}{*}{$\begin{array}{l}0 \\
0 \\
0 \\
0\end{array}$} & \multirow{5}{*}{$\bar{\delta}$} & \multirow{5}{*}{$\stackrel{\tilde{O}}{0}$} & \multirow{5}{*}{8} & \multirow{5}{*}{\begin{tabular}{l}
0 \\
\multirow{o}{*}{} \\
0
\end{tabular}} & \multirow{5}{*}{ 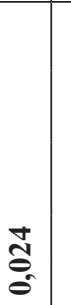 } & \multirow{5}{*}{ 气̊. } & \multirow{5}{*}{$\begin{array}{l}0 \\
0 \\
0 \\
0\end{array}$} & \multirow{5}{*}{$\stackrel{\overbrace{}}{8}$} & \multirow{5}{*}{$\begin{array}{l}\text { o } \\
\vdots \\
0\end{array}$} & \multirow{5}{*}{$\begin{array}{l}\frac{n}{\pi} \\
0 \\
0\end{array}$} \\
\hline $0,0125 \mathrm{ml}$ & & & & & & & & & & & & \\
\hline $0,025 \mathrm{ml}$ & & & & & & & & & & & & \\
\hline $0,0375 \mathrm{ml}$ & & & & & & & & & & & & \\
\hline $0,05 \mathrm{ml}$ & & & & & & & & & & & & \\
\hline
\end{tabular}




\section{Aptarimas}

D žiedadulkių ekstraktas, lyginant su A, B, C ir E ekstraktais, turi stipriausią antimikrobinị veikimą prieš visas tirtas mikroorganizmų kultūras, išskyrus Escherichia coli. Stebètas panašus $\mathrm{C}$ ir D ekstraktų antimikrobinis veikimas prieš gramneigiamas Pseudomonas aeruginosa, Listeria monocytogenes ir Bacillus cereus $(0,025 \mathrm{ml}$ ekstrakto $1 \mathrm{ml}$ agaro). A, B, C ir D ekstraktai neturejjo antimikrobinio veikimo prieš Escherichia coli.

D žiedadulkių ekstrakto stipriausią antimikrobinį veikimą lèmè vietovè, kurioje bitès surinko šias žiedadulkes. Tirtų žiedadulkių ekstraktų skirtingą poveikị ị tirtus mikroorganizmus lèmè fenolinių junginių kiekis žiedadulkèse, su kuriuo ir siejamas antimikrobinis veikimas [6]. Mokslinèse studijose nurodoma, kad mikroorganizmų jautrumas žiedadulkių poveikiui siejamas su dideliu flavonoidų (kvercetino, kaempferolio glikozido) kiekiu bei žiedadulkèse esančiais polifenoliais, riebiosiomis rūgštimis, alkaloidais [8,9]. Žiedadulkių cheminè sudètis gali nežymiai skirtis dèl botaninès ir geografinès kilmès, klimato, dirvožemio tipo, oro sąlygų renkant žiedadulkes ir sezono.

Mokslinèse studijose nustatyta, kad gramteigiamos bakterijos jautresnès žiedadulkių ekstraktų veikimui, lyginant su gramneigiamomis [11]. Gramneigiamas bakterijas antimikrobiškai veikia tik didesnès koncentracijos ekstraktu tirpalai.

Gramneigiamų ir gramteigiamų bakterijų skirtingas atsparumas antibakterinèms medžiagoms siejamas su ląstelès sienelès struktūros skirtumais. Mokslinèse studijose patvirtinta, kad gramneigiamos bakterijos mažiau jautrios antibakterinių medžiagų veikimui dèl išorinès ląstelès sienelès membranos, sudarytos iš lipopolisacharidų, ribojančių ịvairiu junginių judejjimą. Gramteigiamos bakterijos turi tinklelio formos peptidoglikano sluoksnị ląstelès sienelèje, todèl ekstraktas lengviau patenka ị bakteriją. Nevertètų kategoriškai teigti, kad visos gramneigiamos bakterijos yra mažiau jautrios antimikrobinėms medžiagoms, nes mūsų atlikti tyrimai rodo, jog yra gramneigiamų bakterijų rūšių, kurių jautrumas antibakterinèms medžiagoms yra panašus i gramteigiamų $[12,13]$.

\section{Išvados}

1. Stipriausią antimikrobinį veikimą turèjo D žiedadulkių, surinktų Kaišiadorių rajone, ekstraktas.

2. Nustatyta, kad žiedadulkių ekstraktai stipriau veikia gramteigiamąsias bakterijas, lyginant su gramneigiamosiomis.

3. Žiedadulkių sudètyje gausu angliavandenių, lipidų, aminorūgščių, vitaminų, mineralų, fenolių, nukleorūgščių, fermentų. Didžiausią reikšmę turi žiedadulkèse randami polifenoliai - flavonoidai ir fenolinès rūgštys, su kuriomis siejamas antimikrobinis veikimas. Žiedadulkès pasižymi antianeminiu, antiaterosklerotiniu, antialerginiu, priešvěžiniu, priešgrybeliniu, antioksidantiniu ir antimikrobiniu poveikiu.

\section{Literatūra}

1. World Health Organization. 2020.

https://www.who.int/news-room/fact-sheets/detail/antibioticresistance

2. Habryka C, Kruczek M, Drygaś B. Bee products used in apitherapy. World Scientific News 2016; (48):254-258.

https://www.infona.pl/resource/bwmeta1.element.psjd09a97842-03de-4aa6-8cac-fl bc068a7d8c

3. Boukraâ L. Bee products: the rediscovered antibiotics. AntiInfective Agents 2015; 13(1):36-41.

https://doi.org/10.2174/2211352513666150318233855

4. Mărgăoan R, Mărghitaș LA, Dezmirean DS, Gherman B, Chirilă F, Zacharias I, Bobiș O. Antimicrobial activity of bee pollen ethanolic and methanolic extracts on Staphylococcus aureus bacterial strain. Bulletin of University of Agricultural Sciences and Veterinary Medicine Cluj-Napoca. Animal Science and Biotechnologies 2015; 72(1):78-80.

https://doi.org/10.15835/buasvmen-asb:10791

5. Atsalakis E, Chinou I, Makropoulou M, Karabournioti S, Graikou K. Evaluation of phenolic compounds in Cistus creticus bee pollen from Greece. Antioxidant and antimicrobial properties. Natural Product Communications 2017; 12(11):1813-1816. https://doi.org/10.1177/1934578X1701201141

6. Kačániová M, Vatlák A, Vuković N, Petrová J, Brindza J, Nôžková J, Fatrcová-Šrámková K. Antimicrobial activity of bee collected pollen against Clostridia. Scientific Papers Animal Science and Biotechnologies 2015; 47(2):362-365.

http://www.spasb.ro/index.php/spasb/article/view/1868

7. Hleba L. Antimicrobial effect of bee collected pollen extract to Enterobacteriaceae genera after application of bee collected pollen in their feeding. Scientific Papers Animal Science and Biotechnologies 2013;46(2):108-113.

http://www.spasb.ro/index.php/spasb/article/view/183

8. Graikou K, Kapeta S, Aligiannis N, Sotiroudis G, Chondrogianni N, Gonos E, Chinou I. Chemical analysis of Greek pollen-Antioxidant, antimicrobial and proteasome activation properties. Chemistry Central Journal 2011;5(1):1-9.

https://doi.org/10.1186/1752-153X-5-33

9. Didaras NA, Karatasou K, Dimitriou TG, Amoutzias GD, Mossialos D. Antimicrobial Activity of Bee-Collected Pollen and Beebread: State of the Art and Future Perspectives. Antibiotics 2020;9(11):811.

https://doi.org/10.3390/antibiotics9110811

10. Šarkinas A., Čypienè V., Šipailienè A., Venskutonis PR. Gramteigiamų ir gramneigiamų bakterijų jautrumo augalų ekstraktams skirtumai. Maisto chemija ir technologija, 2004;38(1):89- 
96. https://epubl.ktu.edu/object/elaba:6086579

11. Burt S. Essential oils: their antibacterial properties and potential applications in foods - a review. International Journal of Food Microbiology 2004;94(3):223-253.

https://doi.org/10.1016/j.ijfoodmicro.2004.03.022

12. Biswas B, Rogers K, McLaughlin F, Daniels D, Yadav A. Antimicrobial activities of leaf extracts of guava (Psidium guajava L.) on two gram-negative and gram-positive bacteria. International Journal of Microbiology 2013. Article ID 746165. https://doi.org/10.1155/2013/746165

\section{ANTIMICROBIAL ACTIVITY OF POLL EXTRACT COLLECTED IN DIFFERENT LITHUANIAN LOCATIONS}

\section{Ž. Maželienė, G. Lingytè, E. Dailidaitė, I. Viliušienẻ}

Keywords: bee pollen, antimicrobial activity, microorganisms. Summary

Introduction. According to the World Health Organization (WHO), bacterial resistance to antibiotics poses a significant threat worldwide and complicates the treatment of infectious diseases. It is estimated that about 70 percent. bacteria that cause infectious diseases in hospitals are resistant to at least one of the antibiotics used in treatment. It is this situation that encourages the search for other solutions, one of which is to use bee products as natural antibiotics due to their antimicrobial action.

The aim. To determine the antimicrobial activity of pollen extracts collected in different parts of Lithuania.
Methodology. A microbiological study of different concentrations of pollen extract collected in different Lithuanian farms was performed. Antimicrobial activity of 50 samples of pollen extracts against ten cultures of reference bacteria and the fungus Candida albicans was determined. The analysis of the research data was performed using descriptive statistics, calculating frequencies and group comparison according to Kruskal Wallis, the research data were processed using Microsoft Excel 2019 program.

Results. It was found that the extract of D pollen collected in Kaišiadorys district had the strongest antimicrobial effect. The antimicrobial activity of extract D against Staphylococcus epidermidis, Pseudomonas aeruginosa, Bacillus cereus, Listeria monocytogenes was determined in $0.025 \mathrm{ml}$ of extract per $\mathrm{ml}$ of agar. The extract of Staphylococcus aureus, Enterococcus faecalis, Klebsiella pneumoniae, Proteus vulgaris and the fungus Candida albicans, except Escherichia coli, was active in the presence of $0.0375-0.05 \mathrm{ml}$ of agar in $1 \mathrm{ml}$. Pollen extract has a stronger effect on gram-positive bacteria compared to gram-negative ones. This difference is related to the differences in cell wall structure of gram-positive and gram-negative bacteria.

Conclusions. Pollen collected in Kaišiadorys district has the strongest antimicrobial effect. Pollen extracts were found to be more potent against gram-positive bacteria compared to gram-negative ones.

Correspondence to: zaneta.mazeliene@gmail.com

Gauta 2021-10-26 